Klinikal Sains 7 (1) (2019)
JURNERSITAS
UADURRAB
Kttp://jurnal.univrab.ac.id/index.php/klinikal

\title{
GAMBARAN KADAR BILIRUBIN DIRECT PADA PENDERITA TUBERCULOSIS (TB) SEBELUM DAN SESUDAH PENGOBATAN INTENSIF SELAMA SATU BULAN DI PUSKESMAS PEKANBARU
}

\author{
Eli Yusrita ${ }^{1}$, Septri Luciani ${ }^{2}$ \\ Program Studi DIII Analis Kesehatan, Fakultas Kedokteran dan Ilmu Kesehatan, Universitas Abdurrab \\ Jalan Riau Ujung No.73 Pekanbaru \\ Telp. (0761) 38762, 839036 \\ Alamat e-mail: eli.yusrita@univrab.ac.id/yusrita.eli@gmail.com
}

\section{Info Artikel}

SejarahArtikel:

Diterima Januari 2019

Disetujui April 2019

Dipublikasikan Juni 2019

Keywords:

Bilirubin Direct,

Tuberkulosis paru ( $\mathrm{Tb}$ ),

Obat Anti Tuberkulosis

\begin{abstract}
Abstrak
Tuberkulosis merupakan penyakit infeksi yang disebabkan oleh Mycobacterium Tuberculosis yang bersifat menular. Indonesia sendiri menepati urutan ketiga Negara penderita Tuberkulosis (Tb) tertinggi di dunia. Kasus Tuberkulosis (Tb) di Riau dari tahun ketahun semakin meningkat, untuk itu dibutuhkan pengobatan OAT (Obat Anti Tuberkulosis), yang terdiri dari isozianid, etambutom, pirazinamid, rimfampicin, dan streptomisin, yang dikonsumsi selama 6 bulan. OAT memiliki efek samping yang dapat menyebabkan gangguan fungsi hati ditandai dengan meningkatnya kadar bilirubin. Tujuan penelitian ini untuk mengetahui kadar bilirubin direct pada penderita $\mathrm{Tb}$ paru sebelum dan sesudah pengobatan Intensif selama satu bulan di Puskesmas Pekanbaru. Desain yang digunakan pada penelitian ini adalah eksperimen dengan rancangan pre-post analitik, yaitu mengamati perubahan-perubahan yang terjadi pada objek tersebut. Jumlah sampel yang digunakan dalam penelitian ini, sebelum mengkonsumsi obat sebanyak 10 orang dan setelah satu bulan mengkonsumsi obat sebanyak 10 orang. Hasil penelitian kadar bilirubin direct sebelum mengkonsumsi obat persentasenya 50\% diatas normal dan dari hasil penelitian setelah mengkonsumsi obat selama satu bulan presentasenya $40 \%$ diatas normal.
\end{abstract}

Kata Kunci: Bilirubin Direct, Tuberkulosis paru (Tb), Obat Anti Tuberkulosis

\section{Abstract}

Tuberculosis is infection disease which is caused by Mycobacterium Tuberculosis it is contagious. Indonesia got 3 rank in the World for the most Tuberculosis patient. Tuberculosis case in Riau is always increasing every year, so that ATM (Anti Tuberculosis Medicine) is so needed, which is consist of isozianid, entambutom, pirazinamid, and streptomisin, it is cosumed during 6 month. ATM have side effect that can caused heart function disorder it is signified by increasing of Bilirubin level. The purpose of this research is to know the Bilirubin Level Direct to TB patient lung before and after intensive treatment during one month in Community Health Centre Pekanbaru. Design which is used in this research is experiment with design pre-post 
analitic, is observe the chauses which happened to the object. The total of sampel that is used in this research, before consumed the medicine is 10 people and after a month consumed the medicine is 10 people. The result of Bilirubin level Direct before they consumed the medicine the percentage is 50\% over normal, and the result after the patients consumed the medicine during one month the percentage is $40 \%$ over normal.

Key word : Bilirubin Direct, Lung Tuberculosis (Tb), Anti Tuberculosis Drug

C 2019UniversitasAbdurrab

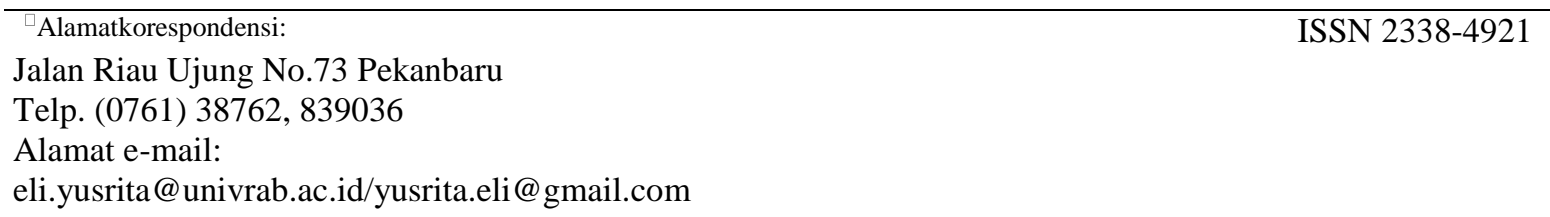

\section{PENDAHULUAN}

Tuberkulosis adalah suatu penyakit infeksi yang disebabkan oleh Mycobacterium tuberculosis dan bersifat menular (Suharyo, 2013). Tuberkulosis merupakan salah satu penyakit yang telah lama dikenal dan sampai saat ini penyebab utama kematian di dunia (Saptawati,dkk, 2012). Berdasarkan laporan WHO pada tahun 2012, angka kesakitan penyakit Tb paru ini yaitu sekitar 8,6 juta jiwa di dunia dan sekitar 1,3 juta jiwa yang meninggal disebabkan penyakit ini. Data pada tahun 2011, jumlah penderita Tb paru di Indonesia diperkirakan prevalensinya 505.614 kasus per tahun dengan 244 per 10.000 penduduk dan 1.550 perhari. Sebagian besar dari orang yang terinfeksi tidak akan menjadi penderita Tb paru, hanya $10 \%$ dari yang terinfeksi yang akan menjadi penderita Tb paru (Pontoh L,dkk, 2016). Di Indonesia Tb paru merupakan masalah utama kesehatan masyarakat karena Indonesia adalah negara dengan prevalensi tuberkulosis ke-3 tertinggi di dunia setelah China dan India.

Berdasarkan angka notifikasi kasus Tb paru tahun 2012 Provinsi Riau ditemukan sebanyak (57) pasien yang baru terdiagnosa positif Tb paru. Pada tahun 2013 sebesar $(60,9)$ per 1.000.000 penduduk. Pada tahun 2014 ditemukan jumlah pasien Tb paru sebesar (91) dalam 1.000.000 penduduk disuatu wilayah. Menurut Data Dinas Kesehatan pada tahun 2015 ditemukan jumlah Kasus Tb paru di Pekanbaru dengan jumlah penduduk laki-laki 533.217 dan perempuan 504.901. Pada BTA positif terdapat 2.356 penduduk $(8,34 \%)$, penderita Tb paru positif terdapat 398 penduduk $(14,10 \%)$ sedangkan pengobatan ulang BTA positif 40 penduduk $(5,34 \%)$ dan BTA negatif 4 penduduk $(0,53 \%)$.

Kasus Tb paru di Riau dari tahun ketahun semakin meningkat, maka perlu dilakukan pengobatan OAT. Lini pertama OAT, terdiri dari obat isoniazid $(\mathrm{H})$, etambutol $(\mathrm{E})$, pirazinamid 
(Z), rifampicin (R) dan streptomisin (S) yang harus diberikan selama 6 bulan, dengan pembagian dosis 2 bulan pertama kombinasi RHZE dan 4 bulan berikutnya kombinasi RH (Pramastuti I, 2011). Metabolisme bilirubin dimulai oleh penghancuran eritrosit setelah usia 120 hari oleh sistem retikuloendotel menjadi heme dan globin. Sebagian besar bilirubin dalam darah normal terikat ke albumin, yaitu bentuk tidak larut atau tidak terkonjugasi (indirect) dan didalam plasma umumnya juga terdapat sejumlah kecil bilirubin terkonjugasi (direct). Kadar bilirubin yang tinggi dapat menyebabkan ikterus. Ikterus adalah keadaan dimana jaringan terutama kulit dan sklera mata menjadi kuning. Ikterus menandakan adanya gangguan metabolisme bilirubin (Rosida, 2016). Tujuan dari penelitian ini adalah untuk mengetahui kadar bilirubin direct pada penderita Tuberkulosis (TB) sebelum mengkonsumsi obat dan setelah mengkonsumsi obat selama 1 bulan di Puskesmas Pekanbaru.

\section{METODE}

Penelitian dilaksanakan dengan menggunakan metode eksperimen dengan rancangan prepost analitik, yaitu mengamati terhadap perubahan-perubahan yang terjadi pada objek tersebut. Sehingga dapat mengetahui gambaran kadar Bilirubin sebelum pengobatan dan setelah pengobatan intensif selama satu bulan pada pasien tuberkulosis paru di puskesmas pekanbaru (Notoatmodjo, 2010). Penelitian ini dilaksankan pada bulan Desember 2016 - Juli 2017. Penelitian dilakukan di Laboratorium Klinik Pekanbaru.

Alat yang digunakan dalam penelitian ini adalah holder, needle, torniquit, kapas kering, plester, tabung tutup merah, spektrofotomer. Adapun bahan yan digunakan dalam penelitian ini adalah serum pasien TB paru dan reagen Bilirubin direct.

\section{Prosedur Kerja}

1. Pengambilan Darah Vena

Identifikasikan pasien dengan jelas, jelaskan posedur yang akan dilakukan lalu siapkan posisi pasien bisa dengan duduk atau berbaring. Siapkan alat dan bahan seperti jarum, holder, tabung, sarung tangan, tourniquet, kapas alkohol, kapas atau kasa steril, plester. Lakukan hand hygiene gunakan sarung tangan. Suruh pasien genggam tangan agar vena mudah teraba. Pasang tourniquet beberapa inci diatas tempat tusukan, kemudian desinfeksi dengan alkohol 70\% dari dalam keluar, biarkan kering. Lalu tusuk vena menggunakan jarum dan holder, setelah darah masuk ke ujung jarum pasang tabung vakum ke holder darah akan mengalir sendirinya kemudian buka tourniquet, letakkan kapas kering diatas tempat tusukan tadi, tarik jarum secara perlahan, lalu letakkan plester diatas tempat tusukan. Beri label pada tabung.

2. Pemisahan Serum 
Tabung vakum yang bertutup merah disiapkan, masukkan darah vena kedalam tabung tersebut sampai batas yang telah ditentukan, kemudian masukkan tabung tersebut kedalam sentrifuge dengan kecepatan 3000 rpm selama 15 menit dan sel-sel darah akan mengendap dan bagian atas cairan akan terpisah berwarna kuning muda, bagian inti disebut serum (Gandasoebrata, 2001).

3. Prosedur Kerja Spektrofotometer

Hidupkan alat dengan cara menekan tombol Switch kearah atas dan hidupkan computer serta monitor, lalu masukkan username dan password. Tunggu beberapa menit sampai program indiko muncul dan masukkan username, tunggu sampai muncul status Startup not Done, lalu klik star up (f1). Tunggu kurang lebih 3 menit sampai status indiko idle. Masukkan reagen yang telah dikeluarkan pada suhu ruangan dengan cara buka cover reagen, setelah itu masukkan rak reagen (barcode menghadap keluar) kemudian tutup cover reagen. Setelah itu masukkan cuvet dengan cara buka cuvet loader, masukkan 1 slot cuvet sampai melewati batas batas panahannya, lalu tarik stikernya kemudian tutup kembali covernya. Sediakan serum atau sampel diatas meja datar, ambil rak sampel masukkan sampel kedalam rak dengan barcode menghadap kedepan. Kemudian buka cover dan masukkan rak kemudian tutup cover, lalu tekan start. Tunggu hasil dan catat hasil.

\section{HASIL DAN PEMBAHASAN}

Adapun hasil yang diperoleh dapat dilihat pada Tabel 1.

Tabel 1 Distribusi Frekuensi Persentase Hasil Pemeriksaan Bilirubin Direct pada Penderita Tuberkulosis Sebelum dan Sesudah Menjalani Pengobatan Intensif Selama Satu Bulan

\begin{tabular}{ccccc}
\hline Kode & Jenis Kelamin & $\begin{array}{c}\text { Umur } \\
\text { (Tahun) }\end{array}$ & \multicolumn{2}{c}{ Kadar Bilirubin Direct } \\
& & $\begin{array}{c}\text { Sebelum } \\
(\mathbf{m g} / \mathbf{d L})\end{array}$ & $\begin{array}{c}\text { Sesudah } \\
\mathbf{m g} / \mathbf{d L}\end{array}$ \\
\hline 1 & $\mathrm{P}$ & 56 & 0,14 & 0,33 \\
2 & $\mathrm{~L}$ & 30 & 0,11 & 0,28 \\
3 & $\mathrm{~L}$ & 56 & 0,19 & 0,21 \\
4 & $\mathrm{~L}$ & 43 & 0,82 & 0,28 \\
5 & $\mathrm{~L}$ & 26 & 0,17 & 0,12 \\
6 & $\mathrm{~L}$ & 33 & 0,25 & 0,35 \\
7 & $\mathrm{P}$ & 45 & 0,23 & 0,23 \\
8 & $\mathrm{~L}$ & 24 & 0,27 & 0,18 \\
9 & $\mathrm{~L}$ & 33 & 0,19 & 0,12
\end{tabular}




\begin{tabular}{ccccc}
10 & $\mathrm{P}$ & 42 & 0,22 & 0,1 \\
\hline Rata-rata & - & - & $\mathbf{0 , 2 5}$ & $\mathbf{0 , 2 2}$ \\
& & & & \\
\hline
\end{tabular}

Berdasarkan tabel 1 diperoleh informasi bahwa jumlah sampel sebelum mengkonsumsi obat $\mathrm{Tb}$ dalam penelitian ini berjumlah 10 orang dan hasil pemeriksaan Bilirubin direct terdapat 5 orang dengan nilai diatas normal karena menunjukkan kadar $>0,20 \mathrm{mg} / \mathrm{dL}$ dan terdapat 5 orang dalam batas normal karena kadar bilirubin directnya $<0,20 \mathrm{mg} / \mathrm{dL}$. Jumlah sampel setelah mengkonsumsi obat $\mathrm{Tb}$ selama 1 bulan dalam penelitian ini berjumlah 10 orang dan hasil pemeriksaan kadar bilirubin direct terdapat 4 pasien mengalami peningkatan nilai diatas normal, dan 5 pasien mengalami penurunan kadar bilirubin direct, dimana 4 pasien masih dalam batas normal, 1 pasien diatas normal, dan 1 pasien kadar bilirubin direct tidak ada perubahan sebelum dan sesudah pengobatan.

Pada penelitian ini sampel yang digunakan adalah penderita tuberkulosis (Tb) sebelum pengobatan dan sesudah pengobatan intensif selama satu bulan dengan jumlah pasien sebanyak 10 orang. Berdasarkan hasil yang didapatkan sebelum pengobatan peresentasenya 50\% (5 orang) kadar bilirubin direct nilai diatas normal. Hasil penelitian setelah dilakukan pemberian OAT kadar bilirubin direct yang mengalami peningkatan persentasenya 40\% (4 orang).

Berdasarkan penelitian Pontoh., dkk 2014, peningkatan bilirubin direct disebabkan oleh adanya cedera iskemik pada hati, yang mengakibatkan terganggunya fungsi dari hati yakni memindahkan bilirubin dari plasma ke empedu, dimana bilirubin direct tidak dapat keluar dari empedu menuju usus sehingga akan masuk kembali ke dalam aliran darah.Kadar bilirubin direct juga dapat meningkat disebabkan oleh adanya hepatotoksik yang dihasilkan oleh obat anti tuberkulosis (OAT).

\section{SIMPULAN}

Berdasarkan hasil penelitian yang diperoleh maka dapat disimpulkan sebagai berikut :

1. Berdasarkan hasil penelitian kadar bilirubin direct sebanyak 10 orang sebelum pengobatan selama 1 bulan menunjukkan kadar bilirubin direct diatas normal pada pasien dengan persentase $50 \%$.

2. Berdasarkan hasil penelitian kadar bilirubin direct sebanyak 10 orang setelah pengobatan selama 1 bulan menunjukkan hasil kadar bilirubin direct yang meningkat persentasenya sebanyak $40 \%$. 


\section{UCAPAN TERIMA KASIH}

Terimakasih kepada semua pihak terkait yang telah membantu dalam bentuk moril atau materil dan bekerjasama demi kelancaran penelitian ini.

\section{DAFTAR PUSTAKA}

Gandasoebrata. 2001. Penuntun Laboratorium Klinik. Dian Rakyat. Jakarta

Notoatmodjo, S. 2010. Metodologi Peneletian Kesehatan. Jakarta: Rineka Cipta

Pontoh, G L., Poli E,F,I dan Gosal Fandy. Gambaran Kadar Bilirubin Pasien Tuberkulosis Paru Selama Pengobatan di RSUD Prof. Dr. R. D. Kandou Manado Periode Januari 2012 Desember 2014, (Online), Jurnal e-Clinic (eCl), Vol 4, No. 1, (http://download.portalgaruda.org/article.php?article=431701\&val=1001\&title=Gambara nkadarbilirubinpasientuberkulosisparuselamapengobatandiRSUP.Dr.R.D.KandouManado periodejanuari2016ả€Desember2014). diakses 26 september 2016

Pramastuti, I. 2011. Hubungan Antara Pemberian Obat Anti Tuberkulosis Terhadap Enzim Transaminase Pada Pasien Tb Kasus Baru Di RSUD Temanggung. Sarjana Kedokteran Universitas Maret Surakarta.

Rosida, A. 2016. Pemeriksaan Laboratorium Penyakit Hati, (Online) Vol 12, No 1,( http://ppjp.unlam.ac.id/journal/index.php/jbk/article/download/364/304). diakses 07 Oktober 2016

Suharyo. 2013. Determinasi Penyakit Tuberkulosis Di Daerah Pedesaan, Jurnal Kesehatan Masyarakat 9 No. 1. (http://journal.unnes.ac.id/nju/index.php/ kemas) diakses. 23 september 2016

Saptawati, Leli., Mardiastuti, Anis Karuniawati, Cleopas Martin Rumende, 2012. Evaluasi Metode FastPlaque TB Untuk Mendeteksi Mycobacterium Tuberculosis Pasa Sputum di Beberapa Unit Pelayanan Kesehatan di Jakarta- Indonesia, Jurnal Tuberkulosis Indonesia, Vol 8. ISSN 1829-5118. 